\title{
Is preterm delivery still related to physical working conditions in pregnancy?
}

\author{
M J Saurel-Cubizolles, D Subtil, M Kaminski
}

\begin{abstract}
Study objective-The aim was to determine the relationship between working conditions during pregnancy, women's occupation, and preterm birth.

Design-This was a retrospective survey. Setting-The study was carried out in four public maternity units in France in 1987 and 1988.

Subjects -1949 women were interviewed after the delivery during their stay in hospital. Of these, 1002 held a job during pregnancy, but this report is confined to 875 women who had a single live birth and who had worked for more than the first trimester of pregnancy.

Measurements and main resultsInformation about social and occupational status was obtained through interviews, and data about gestational length were obtained from medical records. The primary results showed that preterm birth did not vary significantly according to working conditions whereas it differed according to occupational group.

Conclusions-Occupation, but not working conditions, affected the incidence of preterm birth. This result is discordant with other studies which underlined the excess of preterm births among women with strenuous working conditions. Reasons for this discrepancy may include (1) change in perception of "strenuous working conditions"; (2) improved working conditions; (3) the development of "preventive" strategies by pregnant women. Occupation is a more reliable indicator of risk than self described working conditions.
\end{abstract}

During the last 20 years, in France as well as in most European countries, the number of women in the work force has increased, especially married women between 25 and 40 years of age. In France, it was estimated in 1981 that $55 \%$ of women work during pregnancy. ${ }^{1}$

Several studies have established that the preterm delivery rate is lower among working women during pregnancy than among housewives. $^{2-5}$ Nevertheless, the relationship between physically strenuous working conditions and outcome of pregnancy, especially a higher preterm delivery rate, has often been reported. ${ }^{6-9}$

The aim of this study was to analyse women's occupation and working conditions and to discuss their respective roles in relation to preterm delivery.
Methods

The data were collected in a survey conducted between April 1987 and May 1988 in four public maternity units (two in the Paris region, one in the Nord-Pas-de-Calais region, and one in Champagne-Ardennes region). In each unit, a representative sample of births was selected from a chronological list of deliveries. The sampling rate was between $1 / 5$ and $1 / 3$ depending on the unit. Women who had a stillborn baby, and those whose baby died before the interview, were excluded from the survey.

An interviewer questioned the women during their stay in the hospital, after delivery, using a structured questionnaire.

The data collected included demographic and social characteristics, employment before the pregnancy, living conditions and housework, obstetric history, prenatal care, and employment during the pregnancy. For working women, information was recorded about occupation, working conditions, modifications of work, and leave during pregnancy. Medical data relating to the delivery and the health of the newborn infant were extracted from medical records.

A total of 1949 women were included in the sample. Among these women, 1002 had held a job during their pregnancy. For $3 \%(n=30)$ of these employed women, data were incomplete; this group included women who were discharged before the interview $(n=17)$, women who refused to participate $(n=7)$, women who did not speak French $(n=3)$, or very disabled women $(n=3)$.

For this analysis, we excluded women who had worked less than the first three complete months of pregnancy $(n=62)$, women for which this information was not available $(n=24)$, and women who had multiple pregnancies $(n=11)$. The final sample, from which the results were obtained, included 875 women.

Data describing the women's occupation were coded according to the French classification from INSEE,${ }^{10}$ and have been clustered in two groups for statistical reasons. The first group included women with professional, intermediate, and skilled occupations such as teachers, scientists, health and social workers, other professional or intermediate occupations, civil services and clerical staff; the second included women with less qualified occupations such as sales, service, and factory employees.

The description of usual working conditions was obtained from the women's answers. For each working condition, four answers were suggested to the women: not exposed, sometimes, often, and always. These answers were divided into two classes: (a) not exposed/sometimes exposed; (b) often/always exposed. A score of physical exertion 
was defined as the sum of three working conditions: standing position; other arduous positions; and lifting heavy weights. Long working weeks were defined as working more than 45 hours per week. If women had irregular schedules, the longer weeks were taken into account. For the most part, these irregular schedules were found among hospital workers and among some industrial workers doing shift work. Women described the working conditions which characterised their usual job and also some changes which might have occurred in these working conditions during their pregnancy. For each working condition, we asked them if there had been any modification such as increased time spent in a sitting position, lifting heavy weights less often, reduction of the work pace, etc. We classified this information according to whether (a) at least one change was reported, or (b) no change was reported.

The duration of work during pregnancy is indicated by the percentage of women who left their job before the end of the second trimester, whatever the reason for this may have been.

Birth was coded as preterm when delivery occurred before 37 completed weeks of amenorrhoea. Length of gestation was estimated from the last menstrual period. When this information was not available, length of gestation was estimated by the obstetric staff. Because induced labour or caesarean section before labour has recently become more frequent, ${ }^{1}$ a spontaneous preterm birth rate was calculated using the same definition of preterm birth but including only those preterm births for which the onset of labour was spontaneous. The analysis was conducted with both indicators of preterm delivery, but there were more missing data for spontaneous preterm birth than for crude preterm birth rate. For this reason the results recorded here are for crude preterm birth, though some data relating to spontaneous preterm birth are given at the end of the results section.

Some social or demographic characteristics were taken into account as confounding factors: age in five year classes, French or foreign nationality, educational level measured by the highest diploma, gravidity, and previous preterm birth. The maternity unit was also considered, because preterm birth rate, induced labour rate, and social characteristics of population were different in the four units.

Statistical analysis was conducted using SAS software. Two statistical tests were used to compare percentages: the Pearson $\chi^{2}$, and the

Table I Preterm delivery rate according to women's occupation

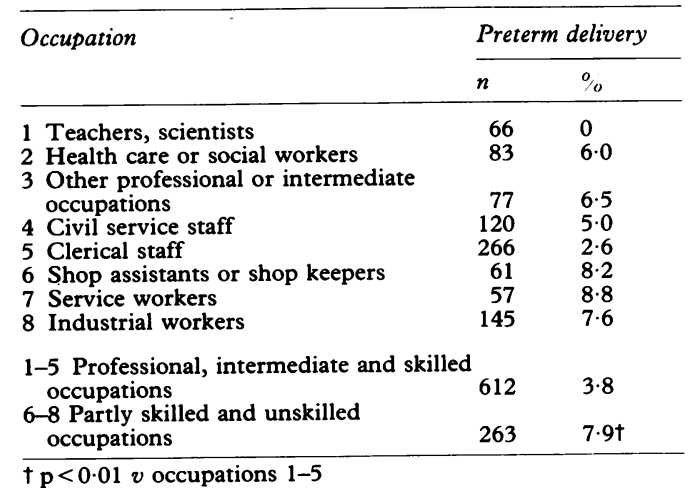

Mantel-Haenszel $\chi^{2}$ when adjusted for confounding variables. ${ }^{11}$ Multivariate analysis was carried out by a logistic regression model using the method of maximum likelihood estimation, ${ }^{12}$ which allowed the calculation of adjusted odds ratios and their confidence limits.

\section{Results}

The preterm delivery rate was significantly different according to occupational group (table I): women in sales, service, and manufacturing jobs had a higher preterm delivery rate than those in managerial, health, or clerical jobs. Teachers and clerical staff had the lowest rates, less than $3 \%$, whereas sales and service workers had the highest rates, higher than $8 \%$.

The occupational groups were characterised by contrasting physical working conditions (table II). Thus women in sales, service and manufacturing jobs worked in a standing or other

Table II Working conditions according to occupational group

\begin{tabular}{lll}
\hline & \multicolumn{2}{l}{ Occupations $^{\mathrm{a}}$} \\
\cline { 2 - 3 } & \multicolumn{2}{l}{$(n=612)(n=263)$} \\
\hline $\begin{array}{l}\text { Standing position } \\
\text { often or always }\end{array}$ & $45 \cdot 7$ & $70 \cdot 0 \dagger$ \\
$\begin{array}{l}\text { Other arduous positions } \\
\text { often or always }\end{array}$ & $21 \cdot 8$ & $49 \cdot 8 \dagger$ \\
$\begin{array}{l}\text { Lifting heavy weights } \\
\text { often or always }\end{array}$ & $22 \cdot 3$ & $43 \cdot 4 \dagger$ \\
$\begin{array}{l}\text { Combination of two or three of these } \\
\text { working conditions }\end{array}$ & $26 \cdot 2$ & $53 \cdot 2 \dagger$ \\
$\begin{array}{l}\text { Working hours per week (maximum) } \\
>45 \text { hours per week }\end{array}$ & $15 \cdot 6$ & 14.9 \\
\hline a See table I & & \\
\hline
\end{tabular}

$\dagger \mathrm{p}<0.001 v$ occupations $1-5$

strenuous position and/or carried heavy weights more often than women in the other occupational groups. A long working week (more than $45 \mathrm{~h}$ ) was no more frequent however.

The preterm delivery rate was slightly higher when working conditions were strenuous, but differences were small and not significant (table III). Among women who had qualified occupations, preterm delivery was significantly more common in those with long working weeks. Among women who had less qualified occupations, preterm delivery seemed slightly more common among women with tiring working conditions, but the differences were not significant.

After adjusting for occupational group, no significant difference in preterm birth was found in relation to working conditions. By contrast, after adjusting for working conditions, the rate of preterm delivery remained significantly higher among sales, service and manufacturing workers than among the other workers.

Using logistic regression, the social and demographic characteristics were taken into account to analyse the relationship between occupational group, working conditions, and preterm birth (table IV). The adjusted odds ratio (OR) for preterm birth was significantly higher than 1 for the underprivileged occupational group ( $\mathrm{OR}=2 \cdot 6 ; 95 \%$ CI $1 \cdot 1-6 \cdot 1)$, whereas the odds ratio for strenuous working conditions was not different from 1. 
Table III Preterm delivery rate according to occupational group and working conditions

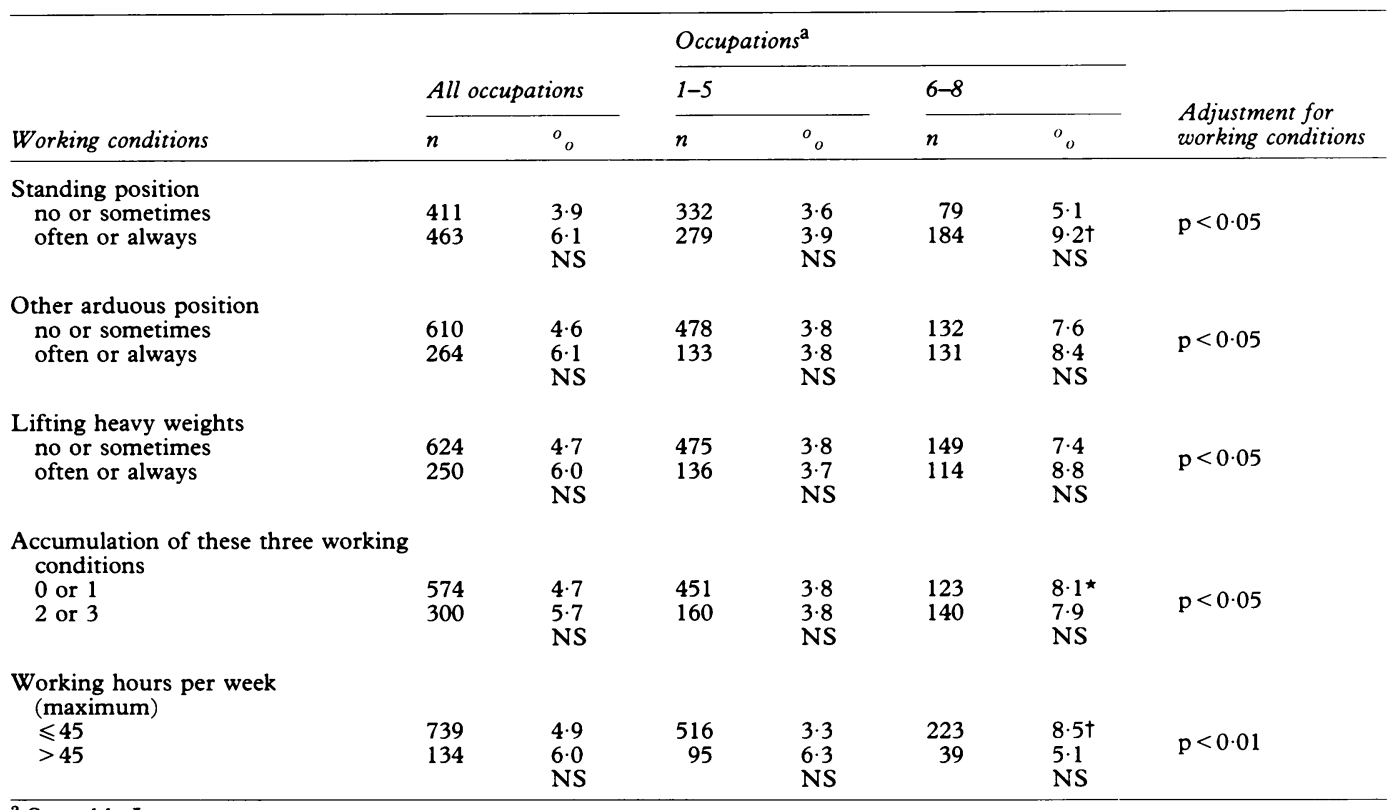

${ }^{\mathrm{a}} \mathrm{See}$ table I $<0.05 ; \mathrm{p}<0.01$ voccupations $1-5$

No significant difference was observed in the antenatal care of these working women; thus the number of visits, visits to specialists, and the date of the first antenatal visit were not statistically different according to occupational group.

Whatever the occupational group, women with strenuous working conditions reported more often that they had changed their working conditions (sitting down more frequently, lifting heavy weights less often, reduction of the work pace, etc) (table V). Moreover, in both groups, these women had often stopped working before the 28th week of the pregnancy.

When working conditions were taken into account, a change in conditions during pregnancy did not remain significantly more frequent among the less qualified occupational group. However,

Table IV Adjusted odds ratios (OR) for preterm delivery according to occupation and working conditions. Controlled for age, nationality, educational level, gravidity, previous preterm birth and maternity centre, $n=861$ women

\begin{tabular}{llll}
\hline & OR & $\begin{array}{l}95^{\circ}{ }_{\text {o }} \text { confidence } \\
\text { limits }\end{array}$ & Significance \\
\hline $\begin{array}{l}\text { Partly skilled or unskilled occupations } \\
\begin{array}{l}\text { Combination of strenuous working conditions } \\
\text { one }\end{array}\end{array}$ & 2.6 & $1 \cdot 1-6 \cdot 1$ & $\mathrm{p}<0.05$ \\
$\begin{array}{l}\text { two or three } \\
\begin{array}{l}\text { Working hours per week (maximum) } \\
>45\end{array}\end{array}$ & 1.4 & $0 \cdot 6-3 \cdot 1$ & $\mathrm{NS}$ \\
& 1.2 & $0.5-2.5$ & $\mathrm{NS}$ \\
\end{tabular}
before the 28 th week, whether or not there was an accumulation of tiring working conditions. Among the women who declared none of these tiring conditions, the percentage of women who stopped working before the 28th week was the same for the two occupational groups.

\section{SPONTANEOUS PRETERM BIRTHS}

Results with spontaneous preterm birth, obtained from 784 women, were very close to those shown for the crude preterm birth rate. The group of partly skilled and unskilled occupations had a spontaneous preterm birth rate of $7 \cdot 4^{\circ}{ }_{0} v 2 \cdot 2^{\circ}$ o among professional, intermediate, and skilled occupations $(p<0.001)$. After adjustment for nationality, age, gravidity and previous preterm birth, educational level, and maternity unit, the odds ratio for spontaneous preterm birth was 3.5 $(95 \%$ CI $1 \cdot 2-10 \cdot 2)$ for the less qualified occupational group whereas the odds ratios were not significantly different from 1 for any working conditions.

\section{Discussion}

The aim of this study was to analyse the effect of pregnant women's occupation and working the women in this group more often left work
Table $V$ Leave and modifications of work during pregnancy according to occupation and working conditions

\begin{tabular}{|c|c|c|c|c|c|c|c|c|c|}
\hline \multirow{3}{*}{$\begin{array}{l}\text { Combination } \\
\text { of three working }\end{array}$} & \multicolumn{4}{|c|}{$\begin{array}{l}\text { o Of women who stopped working } \\
\text { before 3rd trimester: } \\
\text { Occupations }\end{array}$} & \multicolumn{5}{|c|}{$\begin{array}{l}o_{o} \text { Of women who modified their } \\
\text { working conditions: } \\
\text { Occupations }\end{array}$} \\
\hline & \multicolumn{2}{|l|}{$1-5$} & \multicolumn{2}{|l|}{$6-8$} & \multicolumn{2}{|l|}{$1-5$} & & \multicolumn{2}{|l|}{$6-8$} \\
\hline & $n$ & $o_{o}$ & $n$ & ${ }^{o}{ }_{0}$ & $n$ & ${ }^{o}{ }_{o}$ & & $n$ & $o_{0}$ \\
\hline $\begin{array}{l}0 \\
1 \\
2-3\end{array}$ & $\begin{array}{l}305 \\
146 \\
160\end{array}$ & $\begin{array}{l}21 \cdot 0 \\
30 \cdot 8 \\
36 \cdot 3 \\
\ddagger\end{array}$ & $\begin{array}{r}47 \\
76 \\
140\end{array}$ & $\begin{array}{l}21 \cdot 3 \\
36 \cdot 8 \\
55 \cdot 0 \\
\ddagger\end{array}$ & $\begin{array}{l}305 \\
146 \\
160\end{array}$ & $\begin{array}{l}45 \cdot 3 \\
76 \cdot 7 \\
83 \cdot 8 \\
\ddagger\end{array}$ & & $\begin{array}{r}46 \\
76 \\
140\end{array}$ & $\begin{array}{l}63 \cdot 0 \\
82 \cdot 9 \\
80 \cdot 0 \\
\star\end{array}$ \\
\hline $\begin{array}{l}\text { Adjustment for occupational } \\
\text { group }\end{array}$ & & & & & & & $\S$ & & \\
\hline Total & 612 & $27 \cdot 3$ & 263 & $43.7^{\circ}$ & 612 & $62 \cdot 9$ & & 262 & $77.9^{\circ}$ \\
\hline $\begin{array}{l}\text { Adjustment for working } \\
\text { conditions }\end{array}$ & & & & & & & NS & & \\
\hline
\end{tabular}


conditions on preterm birth. Preterm delivery was related to occupation but not to the physical working conditions described by the women. An excess of preterm births was observed among certain occupational groups after controlling for working conditions and social or medical factors.

For women's occupation, the results of this study are in agreement with those previously described. Thus sales, service or manufacturing workers have been found to have a higher rate of preterm birth or low birthweight in several studies. $^{2689}$ From data collected before 1980, various papers have described an increase in preterm birth rate linked with working conditions, especially working in the standing position, physical effort, or lifting heavy weights. ${ }^{346713}$ Some of these authors showed a strong relationship between the accumulation of several strenuous working conditions and preterm delivery. ${ }^{67}$ From a representative sample of births in France in 1981, we did not find a significant relationship between preterm birth and working conditions examined individually, but the association of three or four working conditions (standing position, lifting heavy weights, physical efforts, and work on a conveyor belt) was related to an increase in preterm births. ${ }^{9}$ More recent data have shown the effects of physical working conditions on the outcome of pregnancy less clearly. This trend is illustrated by a summary of the published studies on the specific subject of the effect of working in a standing position on preterm birth (table VI). In 1984, Mamelle and Munoz $^{16}$ did not find the association between preterm birth and posture and physical exertion scores (standing position, physical effort, or load carrying) that they had observed previously, ${ }^{6}$ but these workers showed an increased risk of preterm birth for women working on industrial machines and for women with a routine job or one that was not mentally stimulating. From data collected in Montreal between 1982 and 1984, McDonald et $a^{8}$ failed to show any association between preterm delivery and working in the standing position or with great physical effort, but they described an increased ratio of preterm births in women who lifted heavy weights. From data collected in two hospitals in Finland in 1982, Hartikainen-Sorri and Sorri ${ }^{17}$ found no significant difference between the working conditions of women who had preterm deliveries and controls.

The weakening of the relationship between working conditions and preterm birth needs to be discussed. Several hypotheses can be put forward about methodology on the one hand and development of preventive behaviour on the other.

How accurately have women been reporting their working conditions? Women are likely to evaluate their working conditions in relation to their usual work environment. A woman whose colleagues are usually exposed to strenuous working conditions may evaluate her own working conditions as less tiring than a woman whose usual job does not include frequent physically strenuous tasks. Moreover, some women might hesitate to describe strenuous working conditions because they work in an economically threatened sector (textile or hosiery industry for example). These fears more often affect women with less qualified occupations and working under arduous conditions. These two mechanisms may have led to an underevaluation by women with the most strenuous working conditions. Moreover, on the whole, it can be said that some working conditions have been improved during recent decades, especially the reduction of working hours. ${ }^{18}$ Between 1972 and 1981 , the number of women in France who reported working while standing up during their pregnancy decreased from $48 \%$ to $37 \%$. It is possible that the level of acceptance of strenuous working conditions has become lower and that the work situations now described as strenuous are in fact not the same as those described as such 10 or 20 years ago.

Women belonging to the two occupational groups answered the same questions. One may
Table VI Description of some studies on work in standing position and preterm delivery since 1970

\begin{tabular}{|c|c|c|c|c|}
\hline $\begin{array}{l}\text { Authors } \\
\text { (year of publication) }\end{array}$ & $\begin{array}{l}\text { Period and } \\
\text { place of study }\end{array}$ & Sample studied & $\begin{array}{l}\text { Definition of preterm } \\
\text { delivery }\end{array}$ & $\begin{array}{l}\text { OR related to work } \\
\text { in standing position }\end{array}$ \\
\hline $\begin{array}{l}\text { Goujard } \\
(1979)\end{array}$ & $\begin{array}{l}1972 \\
\text { France }\end{array}$ & $\begin{array}{l}\text { National sample } \\
11200 \text { births } \\
\text { Activity rate: } 57 \%\end{array}$ & $\begin{array}{l}\text { Gestation shorter } \\
\text { than } 37 \text { weeks }\end{array}$ & $1.44(\mathrm{p}<0.01)$ \\
\hline $\begin{array}{l}\text { Saurel-Cubizolles } \\
\text { et al }\end{array}$ & $\begin{array}{l}1976 \\
\text { France }\end{array}$ & $\begin{array}{l}\text { National sample } \\
3218 \text { births } \\
\text { Activity rate: } 61 \%\end{array}$ & $\begin{array}{l}\text { Gestation shorter } \\
\text { than } 37 \text { weeks }\end{array}$ & $1.50(\mathrm{p}<0.01)$ \\
\hline $\begin{array}{l}\text { Mamelle et } a l^{6} \\
(1984)\end{array}$ & $\begin{array}{l}1977-1978 \\
\text { France } \\
\text { (Lyon and Haguenau) }\end{array}$ & $\begin{array}{l}\text { Sample in two hospitals } \\
3437 \text { births } \\
\text { Activity rate: } 56 \%\end{array}$ & $\begin{array}{l}\text { Gestation shorter } \\
\text { than } 37 \text { weeks }\end{array}$ & $1.68(\mathrm{p}<0.001)$ \\
\hline $\begin{array}{l}\text { Saurel-Cubizolles } \\
\text { et al }{ }^{15}(1985)\end{array}$ & $\begin{array}{l}\text { 1979-1981 } \\
\text { France } \\
\text { (Paris) }\end{array}$ & $\begin{array}{l}\text { Sample of women } \\
\text { working in hospital } \\
621 \text { births }\end{array}$ & $\begin{array}{l}\text { Preterm delivery: } \\
\text { at least one month earlier } \\
\text { than the expected date }\end{array}$ & $1.73(\mathrm{p}<0.10)$ \\
\hline $\begin{array}{l}\text { Saurel-Cubizolles } \\
\text { et al } \text { al }^{9}(1987)\end{array}$ & $\begin{array}{l}1981 \\
\text { France }\end{array}$ & $\begin{array}{l}\text { National sample } \\
5508 \text { births } \\
\text { Activity rate: } \mathbf{5 4} \%\end{array}$ & $\begin{array}{l}\text { Gestation shorter } \\
\text { than } 37 \text { weeks }\end{array}$ & $1.29 \mathrm{NS}$ \\
\hline $\begin{array}{l}\text { Hartikainen-Sorri } \\
\text { and Sorri }{ }^{17}(1989)\end{array}$ & $\begin{array}{l}1982 \\
\text { Finland } \\
\text { (Oulu and Tampere) }\end{array}$ & $\begin{array}{l}\text { Case-control survey } \\
284 \text { pairs } \\
\text { Activity rate: } 76 \%\end{array}$ & $\begin{array}{l}\text { Gestation shorter } \\
\text { than } 37 \text { weeks }\end{array}$ & $1.21 \mathrm{NS}$ \\
\hline $\begin{array}{l}\text { McDonald et } a l^{8} \\
(1988)\end{array}$ & $\begin{array}{l}\text { 1982-1984 } \\
\text { Quebec } \\
\text { (Montreal) }\end{array}$ & $\begin{array}{l}\text { Sample in } 11 \text { maternity } \\
\text { units } \\
22761 \text { single live births } \\
\text { (working women, only } \\
\geqslant 30 \text { hours a week) }\end{array}$ & $\begin{array}{l}\text { Gestation shorter } \\
\text { than } 37 \text { weeks }\end{array}$ & $1.07 \mathrm{NS}$ \\
\hline $\begin{array}{l}\text { Mamelle \& Munoz } \\
\text { (1987) }\end{array}$ & $\begin{array}{l}1984 \\
\text { France } \\
\text { (Lyon) }\end{array}$ & $\begin{array}{l}\text { Case-control survey } \\
200 \text { cases, } 400 \text { controls } \\
\text { (working women only) }\end{array}$ & $\begin{array}{l}\text { Gestation shorter } \\
\text { than } 37 \text { weeks }\end{array}$ & $1.00 \mathrm{NS}$ \\
\hline
\end{tabular}


wonder, however, if the answers reflect the same physical effort for women of the two groups, because the nature of their occupations is very different. Moreover, the working conditions were described quite a long time after work had been stopped. Due to this delay, the women's answers may have been influenced by the outcome of their pregnancy. However, this bias should have reinforced the statistical link between working conditions and preterm delivery, because women who had delivered prematurely may have been more likely to have described their job as being tiring. Furthermore, previous surveys which identified the standing position or the accumulation of several strenuous working conditions as risk factors for preterm birth were performed in a similar way and probably included the same inaccuracies.

In the light of these various remarks, occupation appears to be a more objective indicator of the job and does not include these reporting biases.

This study was conducted on a smaller sample of working women than the surveys quoted above, ie, 875 women instead of nearly 2000 or more. ${ }^{4914}$ It is possible that the power of statistical tests was greatly reduced considering the low rate of preterm birth. It is true that the relative risk of preterm birth related to standing position was $1 \cdot 6$, similar to that described by Mamelle $e t a l^{6}$ and higher than the value of 1.3 obtained from national data in $1981 .{ }^{9}$ However, the combination of several working conditions which appeared as a summarised physical load was not correlated with preterm birth in our study, while it clearly was in these other two surveys. ${ }^{69}$

If all of these methodological problems contributed to the reduction in the measured effect of working conditions on preterm birth, they do not entirely explain the lack of association found in our study. Another explanation could be that there has been a reduction of the exposure to physically strenuous working conditions of women during pregnancy.

Periods of leave during pregnancy have increased, particularly among women with arduous working conditions. A great many of these women stop work before the end of the 28th week of pregnancy. In France, the duration of the legal antenatal leave is six weeks for the first or the second pregnancy and eight weeks for the subsequent pregnancies. In addition a two weeks leave is paid for as antenatal leave $(84 \%$ of the salary up to the social security ceiling which was $11040 \mathrm{FF}$ on 1 July 1990) in the case of a pathological pregnancy. All other sick leave is paid for by the national health insurance at a rate of up to $50 \%$ of this salary ceiling when women do not have additional insurance. In $1981,25 \%$ of all working women did not work at all during the third trimester, as compared to $13 \%$ in $1976 .{ }^{1}$ In 1981 , this percentage was $14 \%$ among women with no strenuous working conditions and $28 \%$ among women with a combination of three or four of the following working conditions: standing position, heavy load carrying, assembly line work, or physical effort. ${ }^{9}$ On the other hand, some modifications have occurred in working conditions, especially when these are physically demanding. Most of these modifications, such as a reduction in the amount of time spent standing up or in carrying heavy loads, are decided upon by the women themselves (in preparation). The development of these "preventive measures" could be one reason for the lack of a relationship between certain working conditions and preterm birth. However, very few data support this assertion, and no experimental evaluation has been conducted. The method of our survey does not allow us to assess the effectiveness of pregnancy leave or modifications in working conditions in preventing preterm delivery. Considering the preventive and therapeutic value of pregnancy leave and of certain modifications in work conditions, these various measures are more commonly employed when there is evidence of an abnormal pregnancy.

Nevertheless, the following question still remains: if preventive measures explain the reduction of the link between preterm birth and working conditions, how can the relationship between preterm birth and occupation be better understood?

Firstly, as we have underlined above, occupation describes the job with more objectivity than do working conditions because its categorisation is not dependent on the individual perception of respondents. Secondly, occupation describes much more than the type of job; it is also an indicator of social stratification, social behaviour, income, and so on, all of which factors are probably linked to preterm birth. ${ }^{19} 20 \mathrm{We}$ attempted to take these factors into account by considering specific data such as educational level, nationality and age, and we also considered obstetric history through gravidity and previous preterm birth. It appeared that the occupational group was the "best predictor" of preterm birth among working women during pregnancy, even when the working conditions and the main sociodemographic characteristics were taken into account. This finding suggests that occupation is a summarised indicator of both occupational and social conditions, more discriminant than either of these components.

All of the explanations set forth above are essentially methodological in nature, allowing a clearer understanding of changes which have occurred in this area in recent decades. Nevertheless, it is important to emphasise how dangerous it could be to assume that risks related to strenuous working conditions no longer exist. If this is actually the case in France, and it does need to be confirmed, it is due to the various measures taken at medical and/or social levels. Since rigorous evaluation is lacking, and such evaluation must be the next step in research in this field, we can only suggest some hypotheses. Repeated and/or long periods of pregnancy leave may cause several problems which should not be ignored. They include the following: financial cost for women, feelings of isolation once back at home, association of pregnancy with disease, substitution of occupational tasks by housework, diminished production for the employer, negative impact on women's employment, etc.

While pregnancy leave may pose some problems, modifications in working conditions which would help alleviate some of these often 
require a restructuring of jobs which may involve a significant increase in cost to the employer.

Despite these difficulties, if the jobs which have arduous working conditions were modified as much as possible, various health problems might be solved simultaneously and others could possibly be avoided. From a sample of female hospital workers, it has been shown that the working conditions which were risk factors for preterm birth are the same as those associated with musculoskeletal disorders, the main source of sick leave in this population. ${ }^{21}$

It is also necessary to emphasise that while it may be a positive factor to have reduced the excess preterm birth rate related to strenuous working conditions (if indeed this has been the case), it remains clear that this improvement may only have a limited effect on the reduction of social inequalities on the whole. In fact these social inequalities group together significant differences in living conditions, levels of knowledge, and cultural behaviour. It is probably these very differences, and their effects on health, which we observe when comparing the two occupational groups in our study.

We should like to thank all the women who participated in the survey, the heads of staff and the staff of the four maternity units, the interviewers, and the persons who coded the data. We also thank Dr G Bréart and Dr M Estryn-Behar for their comments, $\mathrm{K}$ Bean who helped us with the translation of the text, and M C Nourry who typed it.

1 Rumeau-Rouquette C, Du Mazaubrun C, Rabarison Y. Rumeau-Rouquette C, Du Mazaubrun C, Rabarison Y. Naître
1984.

2 Ericson A, Eriksson M, Kalen B, Zetterstrom R. Maternal occupation and delivery outcome: a study using central registry data. Acta Paediatr Scand 1987; 76: 512-8.

3 Murphy JF, Dauncey M, Newcombe R, Garcia J, Elbourne D. Employment in pregnancy: prevalence, maternal characteristics, perinatal outcome. Lancet 1984; i: 1163-6.
4 Saurel-Cubizolles MJ, Kaminski M, Rumeau-Rouquette C Activité professionelle des femmes enceintes, surveillance Activite professionelle des femmes enceintes, surveillance prenatale et issue

5 Saurel-Cubizolles MJ, Kaminski M. Work in pregnancy: its evolving relationship with perinatal outcome (a review). evolving relationship with pering

6 Mamelle N, Laumon B, Lazar P. Prematurity and occupational activity during pregnancy. Am $\mathcal{F}$ Epidemiol 1984; 119: 309-22.

7 Saurel-Cubizolles MJ, Kaminski M, Llado-Arkhipoff J, et al. Pregnancy and its outcome among hospital personne according to occupation and working conditions. $\mathcal{f}$ Epidemiol Community Health 1985; 39: 129-34.

8 McDonald AD, McDonald JC, Armstrong B, Cherry NM, Nolin AD, Robert D. Prematurity and work in pregnancy. Br F Ind Med 1988; 45: 56-62.

9 Saurel-Cubizolles MJ, Kaminski M. Pregnant women's working conditions and their changes during pregnancy: a national study in France. Br $\mathcal{f}$ Ind Med 1988; 45: 581-8.

10 INSEE. Nomenclature des professions et catégories socioprofessionelles. Paris: INSEE, 1983.

11 Mantel N, Haenszel W. Statistical aspects of the analysis of data from retrospective studies of disease. $\mathcal{F}$ Natl Cancer Inst 1959; 22: 719-48.

12 Breslow NE, Day NE. Statistical methods in cancer research The analysis of case-control studies. Lyon: IARC Scientific The analysis of case-control stud

13 Papiernik E. Fatigue et résultat de la grossesse. In: Monaco 2 Vers une grossesse sans risque. Courbevoie: Nestlé-Guigoz, 1973: 214-20.

14 Goujard J. Professional activity and working conditions. In Thalhammer O, Baumgarten K, Pollak A, eds. Perinata medicine. Sixth European Congress, Vienna 1978 Stuttgart: Thieme, 1979: 150-3.

15 Saurel-Cubizolles MJ, Kaminski M, Llado-Arkhipoff J, et al. Les femmes enceintes travaillant à l'hôpital: issue de la grossesse et conditions de travail. Rev Fr Santé Publ 1985 30: $27-33$.

16 Mamelle N, Munoz F. Occupational working conditions and preterm birth: a reliable scoring system. Am $\mathcal{F}$ Epidemio 1987; 126: 150-2.

17 Hartikainen-Sorri AL, Sorri M. Occupational and sociomedical factors in preterm birth. Obstet Gynecol 1989; 74 13-16.

18 Ministère du travail, de l'emploi et de la formation professionnelle. Bilan en 1984 des conditions de travail. Document Travail Emploi. Paris: la Documentation Française, 1985.

19 Kramer MS. Determinants of low birth weight: methodological assessment and meta-analysis. Bull WHO 1987; 65: 663-737.

20 Reed DM, Stanley FJ. The epidemiology of prematurity. Munich: Urban and Schwarzenberg, 1977

21 Estryn-Behar M, Kaminski M, Peigne E. Patterns of Estryn-Behar $M$, Kaminski M, Peigne E. Patterns of
strenuous working conditions and musculo-skeletal strenuous working conditions and musculo-skeletal disorders among female hospital workers. 6th International Symposium of Epidemiology in Occupational 